\title{
3 Three new species of Myxobolus Bütschli, 1882 (Myxozoa: 4 Myxobolidae) infecting the common nase Chondrostoma 5 nasus (L.) in the River Danube
}

\author{
6 Gábor Cech • Réka Borzák • Kálmán Molnár • \\ 7 Csaba Székely
}

8 Received: 15 April 2015/ Accepted: 22 June 2015

9 (C) Springer Science+Business Media Dordrecht 2015

10 AQ1 Abstract The common nase Chondrostoma nasus 11 (L.) is a frequent cyprinid fish in the River Danube. In 12 a survey on its infection with myxosporeans, eight 13 different Myxobolus spp. spore types were found in the 14 gills, swim bladder, fins and intestinal wall. Of these, 15 spore types representing three species were studied in 16 detail by morphological and molecular methods. 17 Based on the differences in 18S rDNA sequences, 18 two new species of Myxobolus Bütschli, 1882 from the 19 gills and one from the swim bladder are described: $M$. 20 arrabonensis n. sp., M. szentendrensis n. sp. and $M$. 21 paksensis $\mathrm{n}$. sp. The new species resembled $M$. 22 muelleri Bütschli, 1882, M. intimus Zaika, 1965 and 23 M. cycloides Gurley, 1893, all parasitic in leuciscine 24 cyprinids, in spore size and location in the host, but 25 exhibited differences in partial $18 \mathrm{~S}$ rDNA sequences 26 as follows: M. arrabonensis - M. muelleri (1.4\%), $M$. 27 szentendrensis - M. intimus (2.8\%), M. paksensis - $M$. 28 cycloides $(2.4 \%)$. Based on the significant differences 29 in rDNA sequences, the three forms are considered to 30 represent new, hitherto undescribed species in spite of 31 their morphological similarities to some Myxobolus 32 spp. forming spores in identical locations in geneti33 cally closely related cyprinids of the subfamily 34 Leuciscinae.

G. Cech $(\bowtie)$ · R. Borzák · K. Molnár · C. Székely Institute for Veterinary Medical Research, Centre for Agricultural Research, Hungarian Academy of Sciences, PO Box 18, Budapest 1581, Hungary

e-mail: cech.gabor@agrar.mta.hu
}

\section{Introduction}

The common nase Chondrostoma nasus (L.) is one of the most common cyprinid fishes in European rivers. Molecular studies have demonstrated that this fish is closely related to species of the genera Leuciscus Cuvier and Squalius Bonaparte (see Briolay et al., 1998; Zardoya \& Doadrio, 1999). The myxosporean fauna of the common nase is poorly studied, and only a single species of Myxobolus Bütschli, 1882, M. chondrostomi Donec, 1962, has been described from $C$. nasus as its type-host (Eiras et al., 2005). However, spores of Myxobolus spp. of various shapes and sizes found in different organs of this fish were identified as known species, and Donec \& Shulman (1984) reported C. nasus as a host of 15 Myxobolus spp. originally described from other cyprinid fishes: M. albovae Krasilnikova, 1966; M. bliccae Donec \& Toziyakova, 1984; M. bramae Reuss, 1906; M. carassii Klokacewa, 1914; M. caudatus Gogebashvili, 1966; M. chondrostomi Donec, 1962; M. circulus Akhmerov, 1960; M. cyprini Doflein, 1898; M. dispar Thélohan, 1895; M. donecae Kashkovsky 1969; M. ellipsoides Thélohan, 1892; M. exiguus Thélohan, 1895; M. lobatus Dogiel \& Bychowsky, 1934; M. macrocapsularis Reuss, 1906; and M. musculi Keysselitz, 1908. Due to the relatively strict host-, tissue- and organspecificity of myxosporeans (Molnár, 1994), the majority of spores collected from the common nase but classified to the above Myxobolus spp. might represent undescribed species. In contrast to that of the

\begin{tabular}{|l|lll|}
\hline & Journal : Medium 11230 & Dispatch : 27-6-2015 & Pages : 12 \\
Article No. : 9589 & $\square$ LE & $\square$ TYPESET \\
MS Code : SYPA-D-15-00042 & $\checkmark \mathrm{CP}$ & $\searrow$ DISK \\
\hline
\end{tabular}


common nase, the Myxobolus fauna of other leuciscine fishes is well studied, and several species have been described and/or recorded (Donec \& Shulman, 1984; Lom \& Dyková, 1992; Eiras et al., 2005; Molnár et al., 2006, 2010, 2012; Cech et al., 2012).

This paper presents data on the spore morphology and phylogenetic relationships of three new species of Myxobolus from $C$. nasus in the River Danube in Hungary. Furthermore, the typical infection sites and the histology of plasmodia are also described.

\section{Materials and methods}

\section{Morphological methods}

\section{The myxozoan fauna of the common nase Chondrostoma} nasus (L.) was studied in fish samples caught by fishermen between 1997 and 2014 at six different sampling sites of the River Danube in Hungary: Györ $\left(47^{\circ} 46^{\prime} 06.2^{\prime \prime} \mathrm{N}, 17^{\circ} 41^{\prime} 34.8^{\prime \prime} \mathrm{E}\right)$, Surány $\left(47^{\circ} 42^{\prime} 24.7^{\prime \prime} \mathrm{N}\right.$, $\left.19^{\circ} 07^{\prime} 19.2^{\prime \prime} \mathrm{E}\right), \quad$ Sződliget $\quad\left(47^{\circ} 43^{\prime} 52.9^{\prime \prime} \mathrm{N}, \quad 1^{\circ} 07^{\prime}\right.$ $\left.59.7^{\prime \prime} \mathrm{E}\right)$, Szentendre $\left(47^{\circ} 39^{\prime} 51.1^{\prime \prime} \mathrm{N}, 1^{\circ} 04^{\prime} 51.9^{\prime \prime} \mathrm{E}\right)$ located north of Budapest, as well as Ercsi $\left(47^{\circ} 14^{\prime}\right.$ $\left.49.1^{\prime \prime} \mathrm{N}, \quad 18^{\circ} 54^{\prime} 36.2^{\prime \prime} \mathrm{E}\right)$ and Paks $\left(46^{\circ} 37^{\prime} 11.8^{\prime \prime} \mathrm{N}\right.$, $\left.18^{\circ} 51^{\prime} 42.0^{\prime \prime} \mathrm{E}\right)$ located south of Budapest. Altogether 27 specimens of two- to four-year-old fish (total length, $\mathrm{TL}=18-42 \mathrm{~cm}$ ), were purchased (eight from Györ, seven from Szentendre, four each from Sződliget and Ercsi, and two each from Surány and Paks). Additionally, fingerlings of $C$. nasus were seined or collected by electrofishing. Fish were carried to the laboratory alive, in oxygenated plastic bags, kept in aerated aquaria and subjected to complete parasitological dissection within three days. When mature plasmodia were found, some of the spores were studied as fresh preparations, some were stored in $70 \%$ ethanol until further molecular analysis, and the remaining were mounted in glycerine-gelatine slide preparations. Tissue samples from infected organs containing developing and mature plasmodia were fixed in Bouin's solution, embedded in paraffin wax, cut to 4-5 $\mu \mathrm{m}$ thick sections, and stained with haematoxylin and eosin. The vitality of the spores was checked by adding spores into a $0.4 \%$ urea solution; spores of a given plasmodium were regarded as mature when at least $90 \%$ of the spores extruded polar filaments in this solution. Unfixed spores were studied with an Olympus BH2 microscope equipped with Nomarski differential interference contrast optics. The spores were photographed with an Olympus DP 20 digital camera. All measurements are expressed in micrometres and given as the range followed by the mean \pm standard deviation and the number of measurements (n) in parentheses. Descriptions follow the guidelines of Lom \& Arthur (1989).

Molecular data

DNA was extracted from the spores of single plasmodia (all isolated from different fish specimens) preserved in ethanol using the DNeasy ${ }^{\circledR}$ Blood \& Tissue Kit (Qiagen, Hilden, Germany). The samples were centrifuged at $10,000 \mathrm{rpm}$ for $10 \mathrm{~min}$ and the supernatant was removed. Spore pellets were treated according to the manufacturer's instructions, and $100 \mu \mathrm{l}$ DNA was extracted at the final elution step. The 18S rDNA gene was amplified using nested polymerase chain reaction (PCR). The universal eukaryotic primers ERIB1 and ERIB10 (Barta et al., 1997) were used in the first round PCR. The reaction mixture consisted of $14.4 \mu \mathrm{l}$ nuclease-free water, $2.5 \mu \mathrm{l}$ of $10 \times$ DreamTaq buffer (Thermo Scientific, Vilnius, Lithuania), $0.1 \mu \mathrm{l}$ of DreamTaq polymerase (1 U; Thermo Scientific), $0.2 \mathrm{mM}$ dNTPs (Thermo Scientific), $0.325 \mu \mathrm{M}$ of each primer and $2 \mu \mathrm{l}$ of the extracted DNA in a final volume of $25 \mu \mathrm{l}$. The following profile was used for amplification: an initial denaturation step at $95^{\circ} \mathrm{C}$ for $3 \mathrm{~min}$, followed by 40 cycles at $95^{\circ} \mathrm{C}$ for $1 \mathrm{~min}, 55^{\circ} \mathrm{C}$ for $1 \mathrm{~min}, 72^{\circ} \mathrm{C}$ for $2 \mathrm{~min}$, and completed with terminal extension step at $72^{\circ} \mathrm{C}$ for $7 \mathrm{~min}$.

This was followed by a second round PCR using the myxozoan-specific primers Myx1F and SphR (Hallett \& Diamant, 2001; Eszterbauer \& Székely, 2004). The reaction mixture contained $31.8 \mu \mathrm{l}$ nuclease-free water, $5 \mu$ of $10 \times$ DreamTaq buffer (Thermo Scientific), $0.2 \mu$ of DreamTaq polymerase ( $2 \mathrm{U}$; Thermo Scientific), $0.2 \mathrm{mM}$ dNTPs (Thermo Scientific), $0.325 \mu \mathrm{M}$ of each primer and $1 \mu \mathrm{l}$ from the first round PCR product in a final volume of $50 \mu \mathrm{l}$. The amplification conditions were: $95^{\circ} \mathrm{C}$ for $3 \mathrm{~min}$, followed by 35 cycles at $95^{\circ} \mathrm{C}$ for $50 \mathrm{~s}, 50^{\circ} \mathrm{C}$ for $50 \mathrm{~s}, 72^{\circ} \mathrm{C}$ for $1 \mathrm{~min} 40 \mathrm{~s}$, and terminated with an extension step at $72^{\circ} \mathrm{C}$ for $7 \mathrm{~min}$.

The results of the second round PCR were analysed by electrophoresis in $1 \%$ agarose gel. PCR products were excised from the gel, purified with the Gel/PCR DNA Fragments Extraction Kit (Geneaid, New Taipei City, Taiwan). The purified products were sequenced

\begin{tabular}{|l|lll|}
\hline & Journal : Medium 11230 & Dispatch : 27-6-2015 & Pages : 12 \\
Article No. : 9589 & $\square$ LE & $\square$ TYPESET \\
& MS Code : SYPA-D-15-00042 & $\checkmark \mathrm{CP}$ & $\checkmark$ DISK \\
\hline
\end{tabular}


directly with the primers listed in Table 1 using the BigDye Terminator v3.1 Cycle Sequencing Kit (Life Technologies) with an ABI PRISM ${ }^{\circledR} 3100$ Genetic Analyser (Life Technologies).

Sequence fragments were assembled using MEGA V6.06 (Tamura et al., 2013) and ambiguous bases clarified using corresponding ABI chromatograms. Nucleotide sequences and reference sequences from GenBank based on BLAST matches were aligned with the software CLUSTAL W (Thompson et al., 1994). DNA pairwise distances were calculated with MEGA V6.06 software using the Maximum Composite Likelihood model. Phylogenetic analysis was performed via Maximum Likelihood (ML) and Bayesian Inference (BI); Ceratonova shasta (Noble, 1950) was chosen as the outgroup. The dataset was tested using MEGA V6.06 for the nucleotide substitution model of best-fit and the model, shown by the Akaike Information Criterion (AIC) as the best-fitting one, was chosen $(\mathrm{GTR}+\mathrm{G}+\mathrm{I}$ model $)$. Bootstrap values were generated based on 1,000 resampled datasets. BI was computed using Topali 2.5 (Milne et al., 2004). The likelihood parameters for BI were based on the $\mathrm{GTR}+\mathrm{G}+\mathrm{I}$ model. Posterior probabilities (pp) were estimated over 1,000,000 generations via two independent runs of four simultaneous MCMCMC chains with every 100th tree saved. The first $25 \%$ of the sampled trees were discarded as 'burn in'.

\section{Results}

Fourteen out of the 27 specimens of two- to four-yearold C. nasus were infected with Myxobolus spp. Altogether eight spore types located in different organs and in different types of plasmodia were found in the fish studied, but only three spore types were sequenced and studied by $18 \mathrm{~S}$ rDNA sequence analysis. No infections with Myxobolus spp. were found in 121 fingerlings of common nase collected at Szentendre. PCR amplification of the $18 \mathrm{~S}$ rDNA produced amplicons ranging between 1,600 and 1,700 bp in size. The ten samples analysed belonged to three different species of Myxobolus and the alignment of the different samples and the reference sequences (overall 40 sequences) was $1,731 \mathrm{bp}$ long, of which 692 positions were variable and 479 parsimony informative. ML and BI analyses of the sequences generated highly similar topologies, except for some branches with low support and the location of M. sitjae Cech, Molnár \& Székely, 2012 (see Figs. 1, 2), but the phylogenetic positions of the three new species were identical on both phylograms. All three spore types differed from similar spores from genetically closely related fish hosts and proved to be undescribed species specific to $C$. nasus. There are no available sequence data of Myxobolus chondrostomi for comparison. Some of the other species (M. bliccae, M. bramae, $M$. dispar and M. macrocapsularis) reported for this host by Donec \& Shulman (1984) are presented on the phylogenetic tree, but their sequences were not identical with any of our samples found in the present study.

Myxobolus arrabonensis n. sp. possessed small short elliptical spores and formed large plasmodia in the arteries of the gill filaments. Myxobolus szentendrensis $\mathrm{n}$. sp. developed in small plasmodia inside the gill lamellae and had spores resembling those of $M$. intimus, a parasite of the roach. Myxobolus paksensis

Table 1 Primers used for PCR or sequencing

\begin{tabular}{llll}
\hline Primer & Sequence & Application & Source \\
\hline ERIB1 & $5^{\prime}$-ACCTGGTTGATCCTGCCAG-3' & $1^{\text {st }}$ round PCR & Barta et al. (1997) \\
ERIB10 & $5^{\prime}$-CTTCCGCAGGTTCACCTACGG-3' & $1^{\text {st }}$ round PCR & Barta et al. (1997) \\
Myx1F & $5^{\prime}$-GTGAGACTGCGGACGGCTCAG-3' & $2^{\text {nd }}$ round PCR & Hallett \& Diamant (2001) \\
SphR & $5^{\prime}$-GTTACCATTGTAGCGCGCGT-3' & $2^{\text {nd }}$ round PCR and sequencing & Eszterbauer \& Székely (2004) \\
ACT1fr & $5^{\prime}$-TTGGGTAATTTGCGCGCCTGCTGCC-3' & sequencing & Hallett \& Diamant (2001) \\
MC5 & $5^{\prime}$-CCTGAGAAACGGCTACCACATCCA-3' & sequencing & Molnár et al. (2002) \\
MC3 & $5^{\prime}$-GATTAGCCTGACAGATCACTCCACA-3' & sequencing & Molnár et al. (2002) \\
MB5r & $5^{\prime}$-ACCGCTCCTGTTAATCATCACC-3' & sequencing & Eszterbauer (2004) \\
MB5f & $5^{\prime}$-GATGATTAACAGGAGCGGTTGG-3' & sequencing & Eszterbauer (2004) \\
\hline
\end{tabular}

\begin{tabular}{|l|lll|}
\hline & Journal : Medium 11230 & Dispatch : 27-6-2015 & Pages : 12 \\
Article No. : 9589 & $\square$ LE & $\square$ TYPESET \\
& MS Code : SYPA-D-15-00042 & $\cup_{\mathrm{CP}}$ & $\searrow$ DISK \\
\hline
\end{tabular}




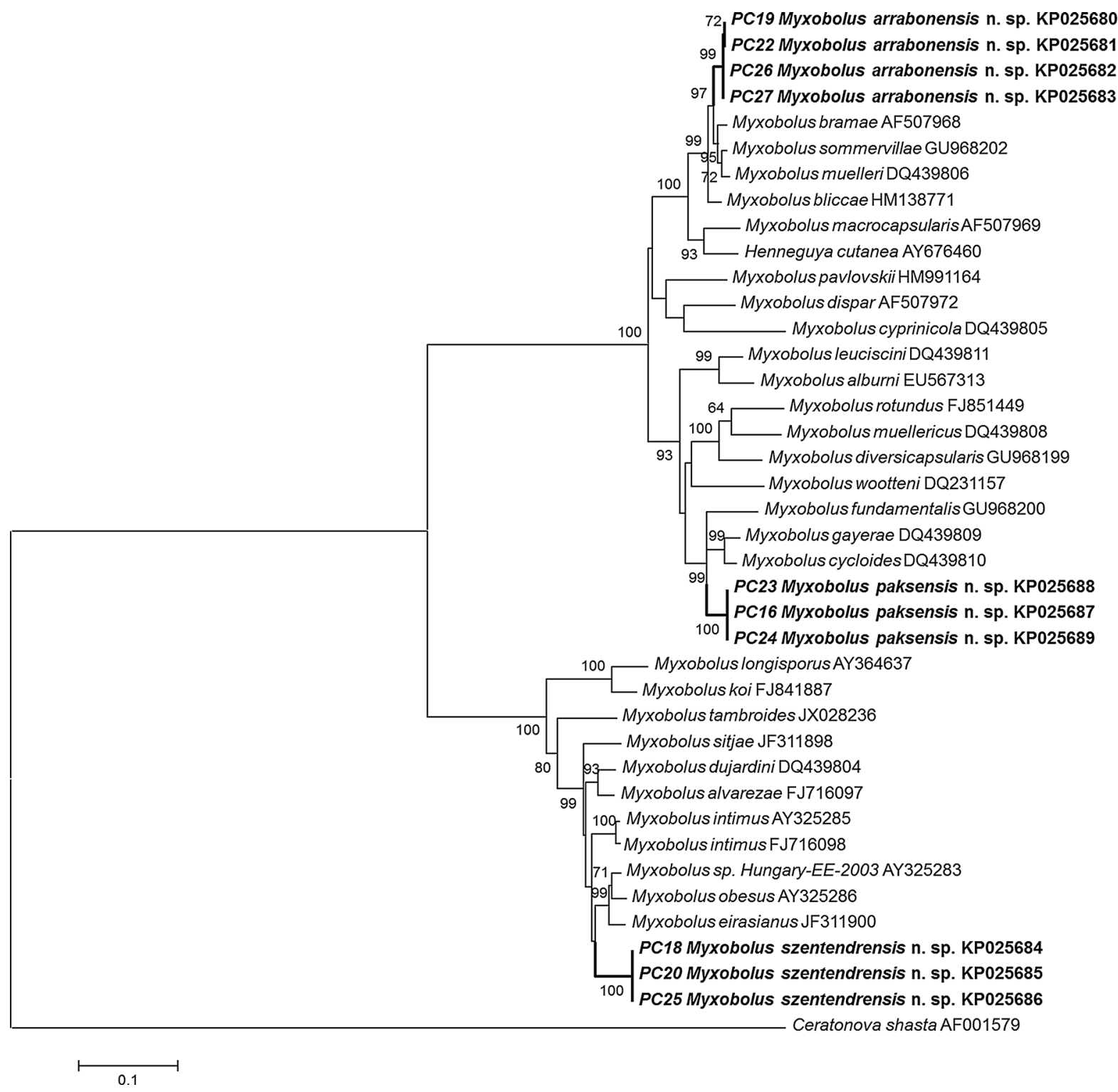

Fig. 1 Phylogenetic position of the new species of Myxobolus ex Chondrostoma nasus based on the 18S rDNA by Maximum Likelihood algorithm. Ceratonova shasta was used as the outgroup. Bootstrap values are given at the nodes. Bootstrap values under 70 were omitted. Scale-bar indicates the number of expected substitutions

224 n. sp. had large ellipsoidal spores formed in round 225 plasmodia on the surface of the swim bladder.

Myxobolus arrabonensis $\mathrm{n}$. sp.

227 Type-host: Common nase, Chondrostoma nasus (L.) 228 (Cyprinidae).

229 Type-locality: River Danube at Györ $\left(47^{\circ} 46^{\prime} 06.2^{\prime \prime} \mathrm{N}\right.$, $\left.23017^{\circ} 41^{\prime} 34.8^{\prime \prime} \mathrm{E}\right)$ Hungary.
Other localities: River Danube close to Szentendre, Sződliget and Surány, cities located north of Budapest, Hungary.

Site of tissue development: Gill filaments.

Prevalence: $15 \%$ (4/27 specimens; TL $=18-42 \mathrm{~cm})$.

Intensity: 2 to 18 plasmodia per hemibranch.

Type-material: Photo-types and histological sections were deposited in the parasitological collection of the

\begin{tabular}{lll} 
Journal : Medium 11230 & Dispatch : 27-6-2015 & Pages : 12 \\
Article No. : $\mathbf{9 5 8 9}$ & $\square$ LE & $\square$ TYPESET \\
MS Code : SYPA-D-15-00042 & $\checkmark$ CP & $\checkmark$ DISK \\
\hline
\end{tabular}




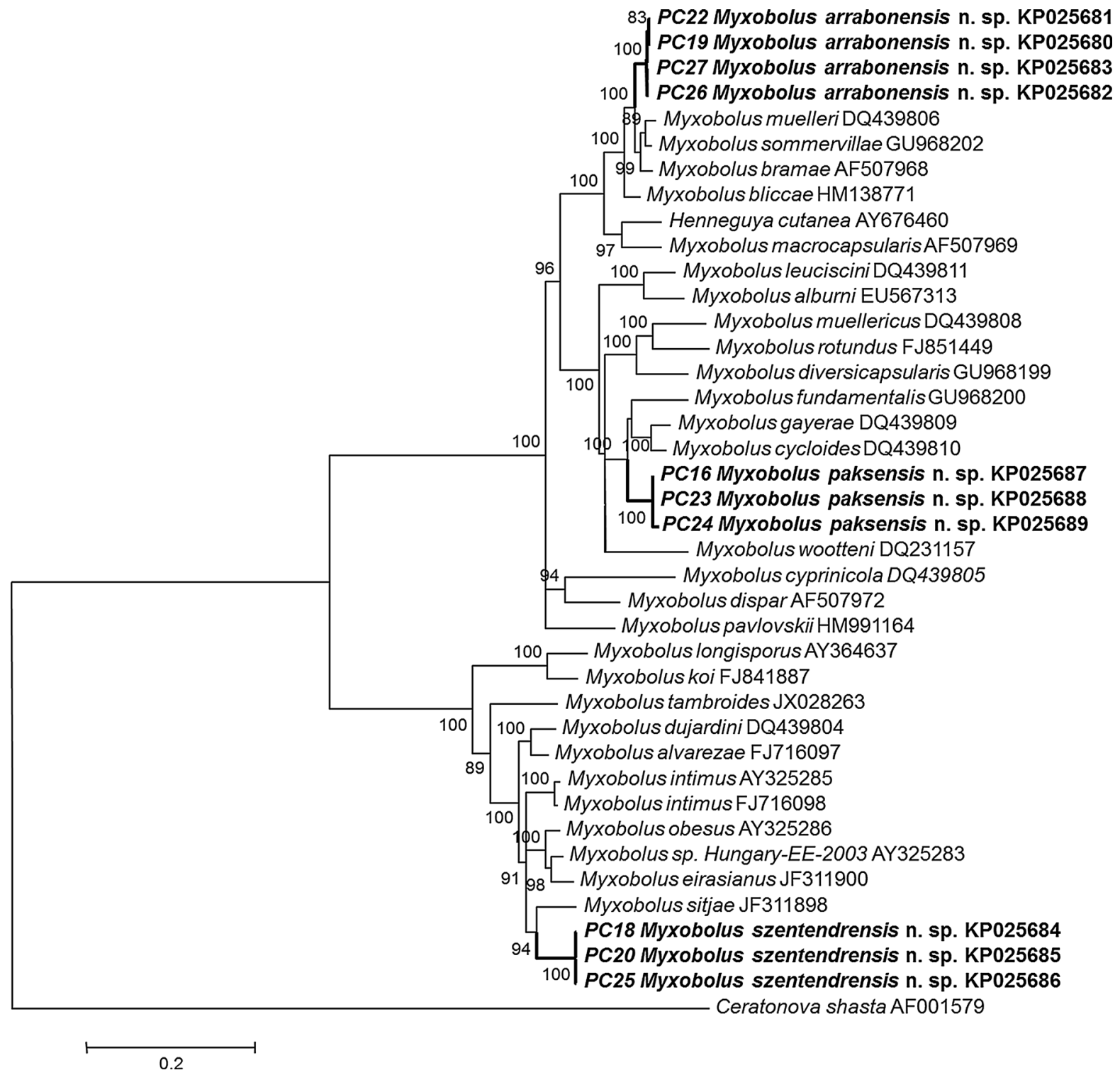

Fig. 2 Phylogenetic position of the new species of Myxobolus ex Chondrostoma nasus based on the 18S rDNA by Bayesian Inference algorithm. Ceratonova shasta was used as the outgroup. Posterior probabilities (only $>0.7$ shown) are given at the nodes. Scale-bar indicates the number of expected substitutions per site

Description (Figs. 3,4A, 5A, B)

Vegetative stages

Elongated plasmodia of this species, reaching 1.0-1.5 $\mathrm{mm}$ in size, were located inside the afferent artery of the central and distal part of the gill filaments (Fig. 3).

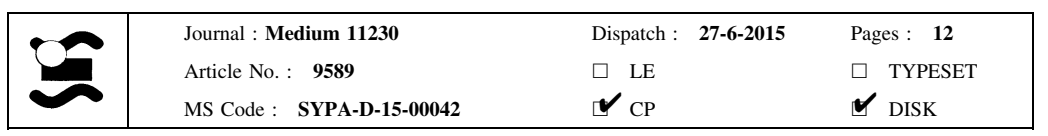




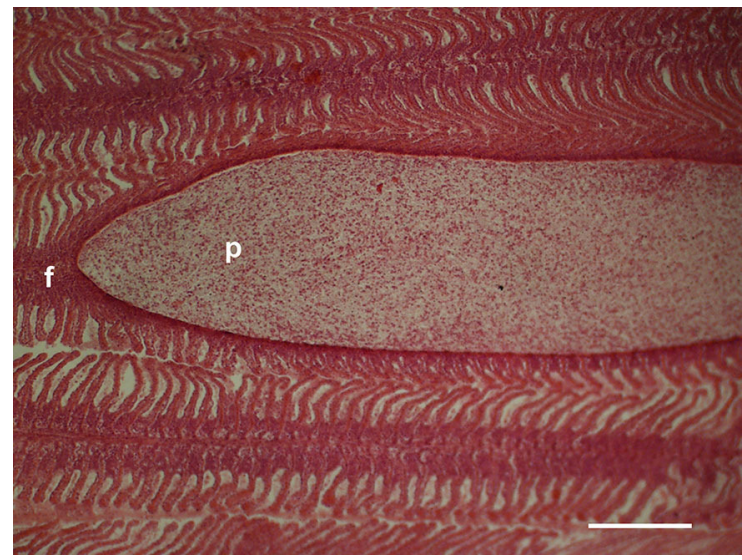

Fig. 3 A large plasmodium (p) of Myxobolus arrabonensis n. sp. in the aorta of the gill filament (f). Histological section (haematoxylin and eosin staining). Scale-bar: $100 \mu \mathrm{m}$

Spores
Spores small, ellipsoidal or short ellipsoidal in frontal view (Figs. 4A, 5A), lemon-shaped in sutural view (Figs. 4A inset, 5B). Length of spores 8.4-10 $(8.7 \pm 0.61)(\mathrm{n}=50)$, width $7.6-8(7.8 \pm 0.34)$ $(\mathrm{n}=50)$, thickness 5.4-5.6 (5.5) $(\mathrm{n}=12)$. Polar capsules 2, pyriform, subequal in size, 4.5-5.9 $(4.8 \pm 0.44)$ long $(n=50), 2.7-3.1 \quad(2.9 \pm 0.12)$ wide $(\mathrm{n}=50)$, tapering toward discharging canals of polar filaments. Polar filaments coiled with 6 turns in polar capsule, situated perpendicularly to its longitudinal axis. Spore intercapsular appendix at anterior end relatively large, triangular, 1.3-1.9 (1.5) long $(\mathrm{n}=10)$. Sutural line indistinct; sutural edge moderately protruding. Valves thin, symmetrical, smooth with indistinct $4-6$ edge markings. Sutural extensions present, c.0.6 at anterior and 1 at posterior pole of spores. Sporoplasm nuclei indiscernible; small iodinophilous vacuole found in sporoplasm; mucous envelope not observed.

Molecular data

The 18S rDNA sequences of four isolates of Myxobolus arrabonensis n. sp. (KP025680- KP025683) collected from the gill filaments of four fish specimens showed $100 \%$ similarity. The highest similarity (98.5\%) to other sequenced myxosporeans was that to M. sommervillae Molnár, Marton, Székely \& Eszterbauer, 2010 (GU968202). The new species was also similar (98.4\%) to M. bramae (AF507968)
Fig. 4 Spores of the new species of Myxobolus ex Chondrostoma nasus. A, M. arrabonensis n. sp., frontal view (inset: sutural view); B, M. szentendrensis n. sp., frontal view (inset: sutural view); C, M. paksensis n. sp., frontal view (inset: sutural view). Scale-bars: $10 \mu \mathrm{m}$

and M. muelleri Bütschli, 1882 (DQ439806), and to $M$. bliccae (HM138771) (98.1\%).

Remarks

The new species seems to be a typical vascular species forming large plasmodia in the gill arteries. In morphology and size, the spores of Myxobolus arrabonensis $\mathrm{n}$. sp. were very similar to those of M. muelleri, M. bramae and M. sommervillae but had a somewhat more roundish form. The $1.5-1.9 \%$ differences between the $18 \mathrm{~S}$ rDNA sequences of $M$. arrabonensis n. sp. and those of $M$. bramae (AF507968), $M$. sommervillae (GU968202), M. muelleri (DQ439806) and M. bliccae (HM138771), indicate that M. arrabonensis $\mathrm{n}$. sp. should be regarded as a new species.

Myxobolus szentendrensis n. sp.

Type-host: Common nase, Chondrostoma nasus (L.) (Cyprinidae).

300

Type locality: River Danube at Szentendre $\left(47^{\circ} 39^{\prime} 51.1^{\prime \prime} \mathrm{N}, 19^{\circ} 04^{\prime} 51.9^{\prime \prime} \mathrm{E}\right)$, Hungary.

Other localities: River Danube, close to Surány and Györ, Hungary.

Site of tissue development: Gill lamellae.

Prevalence: $18 \%$ (5/27 specimens; TL $=18-42 \mathrm{~cm})$. Type-material: Photo-types and histological sections were deposited in the parasitological collection of the Zoological Department, Hungarian Natural History Museum, Budapest (Coll. No. HNHM-18911.

Representative sequences: GenBank accession numbers KP025684-KP025686 (18S rDNA).

Etymology: The name of the species is after the name of the type-locality.

Description (Figs. 4B, 5C, D, 6)

Vegetative stages

Small round or roundish plasmodia 60 to 130 in 318 diameter, containing 3,500 to 5,000 spores, developed 319 in the capillary network of the gill lamellae (Fig. 6).

\begin{tabular}{lll} 
Journal : Medium 11230 & Dispatch : 27-6-2015 & Pages : 12 \\
Article No. : $\mathbf{9 5 8 9}$ & $\square$ LE & $\square$ TYPESET \\
MS Code : SYPA-D-15-00042 & $\checkmark$ CP & $\checkmark$ DISK \\
\hline
\end{tabular}



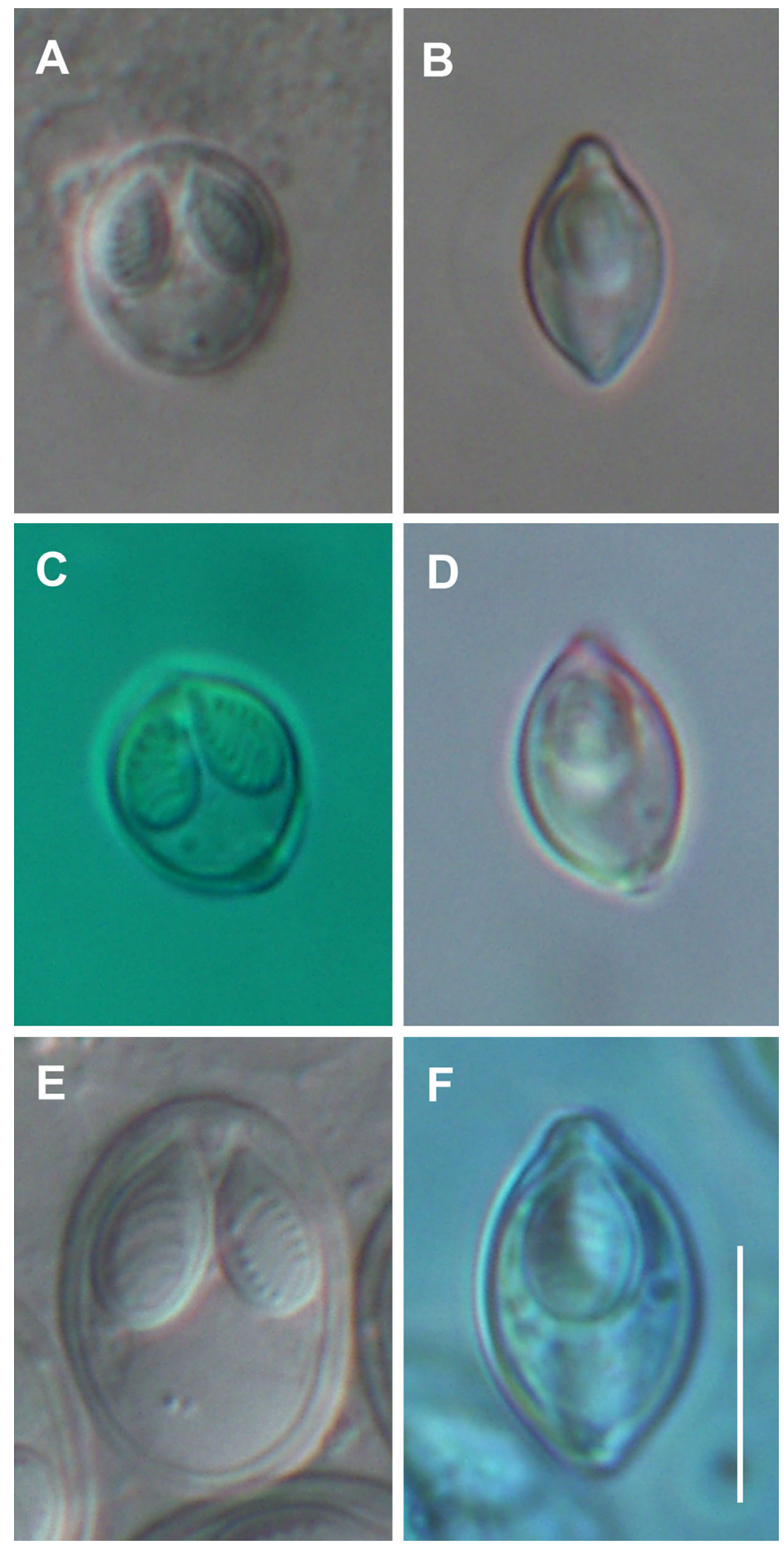

\begin{tabular}{|l|lll|}
\hline Journal : Medium 11230 & Dispatch : 27-6-2015 & Pages : 12 \\
Article No. : 9589 & $\square$ LE & $\square$ TYPESET \\
& MS Code : SYPA-D-15-00042 & $V_{\mathrm{CP}}$ & $\checkmark$ DISK \\
\hline
\end{tabular}


A

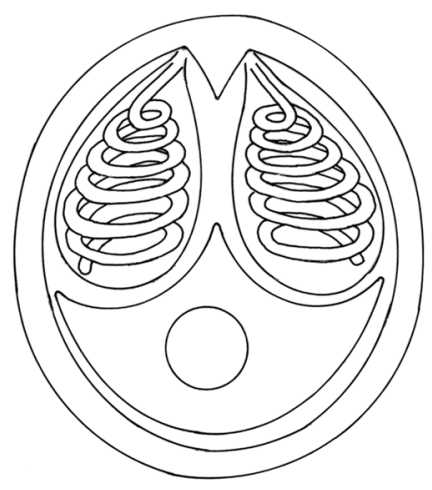

C

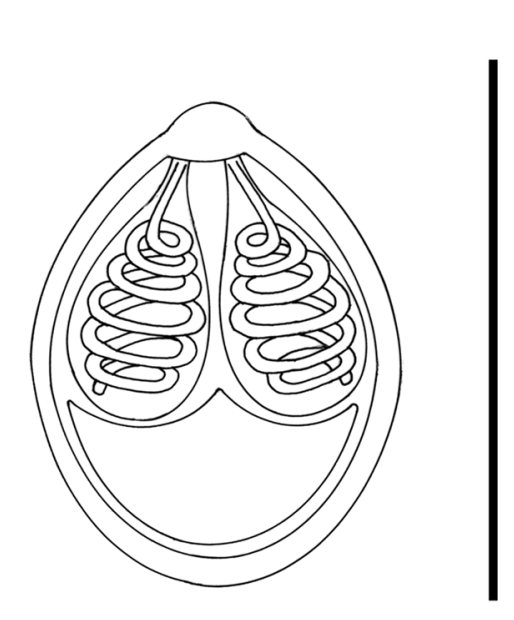

E

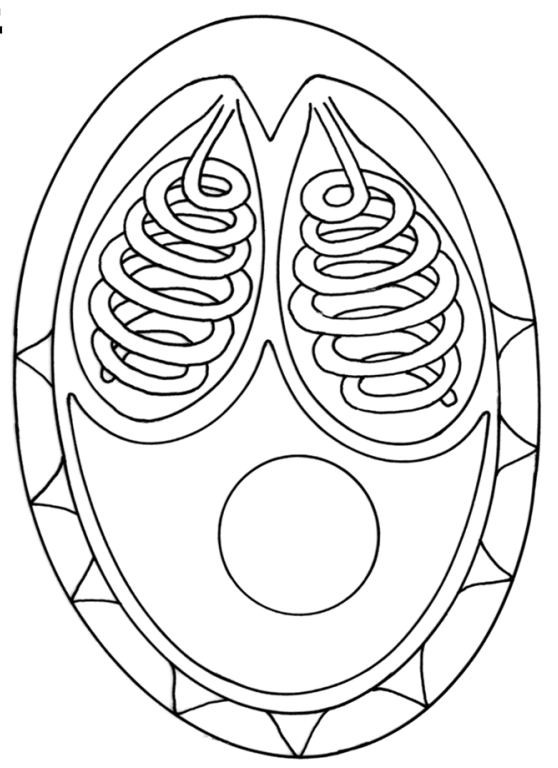

B

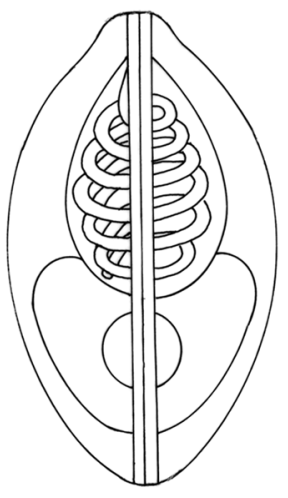

D

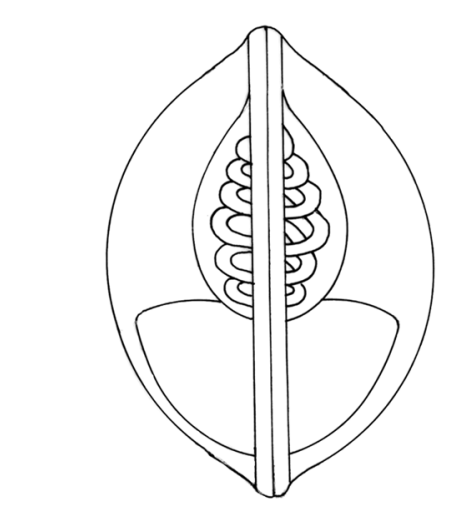

F

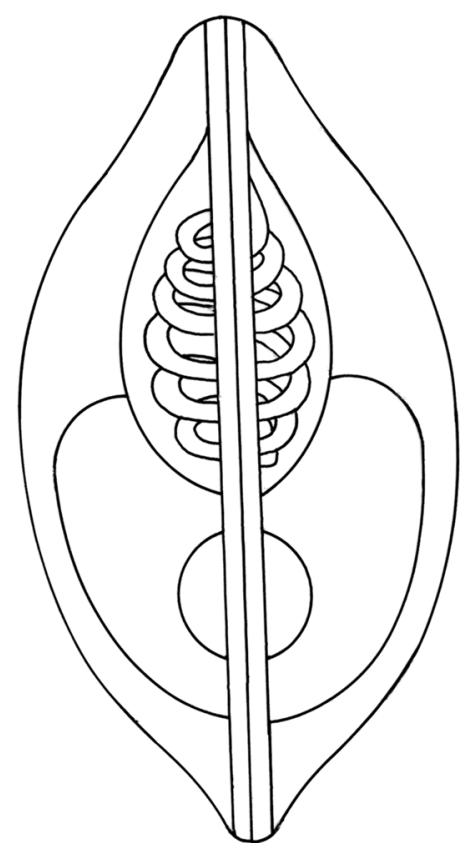


4 Fig. 5 Schematic drawings of spores of the new species of Myxobolus ex Chondrostoma nasus. A, M. arrabonensis n. sp., frontal view; B, M. arrabonensis n. sp., sutural view; C, $M$. szentendrensis. n. sp., frontal view; D, M. szentendrensis n. sp., sutural view; E, M. paksensis n. sp., frontal view; F, $M$. paksensis n. sp., sutural view. Scale-bar: $10 \mu \mathrm{m}$

\section{$321 \quad$ Spores}

322

323

324

325

326

327

328

329

330

331

332

333

334

335

336

337

338
Spores pyriform in frontal view (Figs. 4B, 5C) with well-defined extrusion at anterior end and lemon shaped in sutural view (Figs. 4B inset, 5D). Length of spores $8.8-9.6(9.2 \pm 0.34)(\mathrm{n}=50)$, width $7.6-8$ $(7.9 \pm 0.74) \quad(\mathrm{n}=50), \quad$ thickness $6.4-7.1 \quad(6.7)$ $(\mathrm{n}=11)$. Polar capsules 2 , pyriform, equal in size, slightly converging anteriorly, 4.8-5.6 (5.3 \pm 0.29$)$ long $(\mathrm{n}=50), 2.8-3.2(3.0 \pm 0.17)$ wide $(\mathrm{n}=50)$. Polar filament coils 6 , arranged perpendicular or oblique to capsule longitudinal axis, coiled densely in polar capsule. No intercapsular appendix observed. Sutural protrusion with relatively thick circular rim around spore, emerging $c .0 .5$ over spore surface; in sutural view rim of suture emerging from spore surface c. 0.5 at both anterior and posterior poles. Sutural edge markings not seen. No iodinophilous vacuole in single binucleated sporoplasm.

\section{Molecular data}

The 18S rDNA sequences of three isolates of Myxobolus szentendrensis $\mathrm{n}$. sp. were identical. The highest similarity (96.6\%) was found to Myxobolus sp.

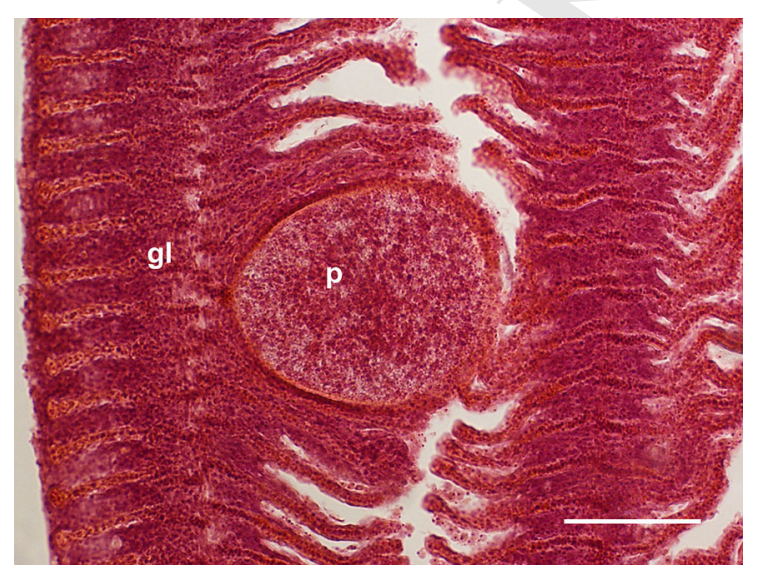

Fig. 6 Plasmodium (p) of M. szentendrensis n. sp. in a gill lamella (gl) of Chondrostoma nasus. Histological section (haematoxylin and eosin staining). Scale-bar: $60 \mu \mathrm{m}$
Hungary EE-2003 (AY325283). The new sequences were also similar to M. intimus (96.3\%; AY325285 and FJ716098), M. eirasianus Cech, Molnár \& Székely, 2012 (96.2\%; JF311900) and M. obesus Gurley, 1893 (96.4\% AY325286).

Remarks

The new species seems to be a typical vascular species forming small plasmodia in the gill lamellae. The spores of Myxobolus szentendrensis $\mathrm{n}$. sp. were very similar to those of $M$. intimus and M. eirasianus in morphology and size, but had a somewhat more roundish shape. The $c .3 \%$ differences between the $18 \mathrm{~S}$ rDNA sequences of $M$. szentendrensis $\mathrm{n}$. $\mathrm{sp}$. and those of M. intimus (FJ716098) and M. eirasianus (JF311900) indicate that the present material should be regarded as a new species.

\section{Myxobolus paksensis n. sp.}

Type-host: Common nase, Chondrostoma nasus (L.) (Cyprinidae).

Type-locality: River Danube at Paks $\left(46^{\circ} 37^{\prime} 11.8^{\prime \prime} \mathrm{N}\right.$, $\left.18^{\circ} 51^{\prime} 42.0^{\prime \prime} \mathrm{E}\right)$, Hungary.

Other localities: River Danube close to Györ and Szentendre, Hungary.

Site of tissue development: Swim bladder.

Prevalence: $11 \%$ (3/27 specimens; TL $=18-42 \mathrm{~cm})$. Intensity: 1 to 8 plasmodia per swim bladder.

Type-material: Photo-types were deposited in the parasitological collection of the Zoological Department, Hungarian Natural History Museum, Budapest (Coll. No. HNHM-18912).

Representative sequences: GenBank accession numbers KP025687-KP025689 (18S rDNA).

Etymology: The name of the species is after the name of the type-locality.

360

361

362

363

364

365

366

367

368

369

370

371

372

373

374

375

376

Description (Figs. 4C, 5E, F, 7)

Vegetative stages

Large flat plasmodia 1 to $1.7 \mathrm{~mm}$ in size, located in the multilayered connective tissue of the swim bladder, covered by a thin epithelial layer (Fig. 7), containing large-sized ellipsoidal spores.

\begin{tabular}{|l|lll|}
\hline & Journal : Medium 11230 & Dispatch : 27-6-2015 & Pages : 12 \\
Article No. : 9589 & $\square$ LE & $\square$ TYPESET \\
& MS Code : SYPA-D-15-00042 & $\checkmark \mathrm{CP}$ & $\checkmark$ DISK \\
\hline
\end{tabular}




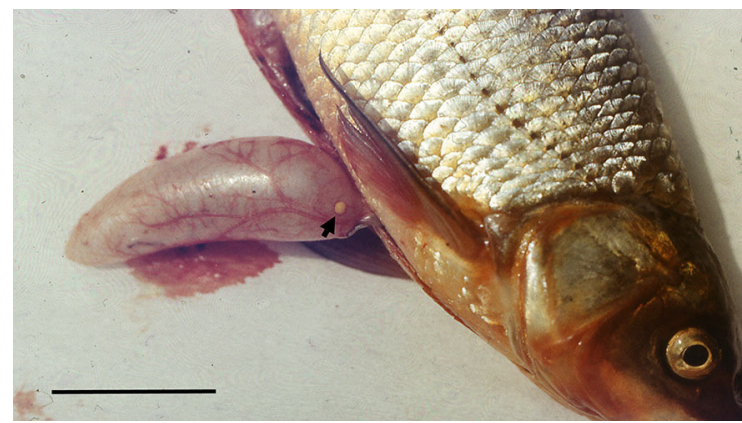

Fig. 7 Plasmodium (arrowed) of M. paksensis n. sp. in the swim bladder of Chondrostoma nasus. Scale-bar: $5 \mathrm{~cm}$

\section{Spores}

Molecular data

Spores relatively large, ellipsoidal in frontal view (Figs. 4C, 5E) and lemon shaped in sutural view (Figs. 4C inset, 5F). Spores 14.4-15.2 (14.8 \pm 0.62$)$ long $(\mathrm{n}=50), 10.4-12(11 \pm 0.68)$ wide $(\mathrm{n}=50)$, 8.4-9.2 (8.7) thick $(n=14)$. Polar capsules 2 , pyriform, equal in size, slightly converging anteriorly, 6.8-7.6 (7.0 \pm 0.39$) \quad$ long $\quad(\mathrm{n}=50), \quad 4-4.6$ $(4.3 \pm 0.21)$ wide $(n=50)$. Polar filament coils 6 , arranged obliquely to capsule longitudinal axis. Intercapsular appendix relatively small, 1.6-2.3 (2) $(\mathrm{n}=16)$, triangular, located anteriorly between capsules. Sutural protrusion with circular rim around spore emerging c.0.9-1.2 over spore surface (Figs. 4C, 5E). Rim 1 thick in sutural view, forming sutural protrusions 1 to 1.3 at anterior pole and $0.5-0.8$ at posterior pole. Sutural edge markings rarely seen in fresh spores. Single binucleated sporoplasm with large, round iodinophilous vacuole present; mucous envelope not observed.

The three identical 18S rDNA sequences of isolates of Myxobolus paksensis n. sp. (KP025687- KP025689) collected from the swim bladder of three fish specimens showed the highest similarity $(96.8 \%)$ to $M$. cycloides (DQ439810). The sequence for the new species was also similar to M. gayerae Molnár, Marton, Eszterbauer \& Székely, 2007 (96.7\%; DQ439809) and M. fundamentalis Molnár, Marton, Székely \& Eszterbauer, 2010 (95.5\%; GU968200).
Remarks

The new species develops typically in the multilayered, dense connective tissue of the swim bladder wall. The location of plasmodia was the same as in $M$. cycloides, but the cysts of M. paksensis n. sp. differ from those of $M$. cycloides in the round shape and typically yellow colour of the plasmodia on the swim bladder ( $v s$ less regular shape and white colour, respectively, in $M$. cycloides). Similarly, the spores of the two species are similar in size and shape but the 18S rDNA sequences of $M$. paksensis $\mathrm{n}$. sp. differed from those of $M$. cycloides by $3.2 \%$. The sequences for $M$. paksensis n. sp. also resemble those for $M$. fundamentalis, but differed by $4.5 \%$. Differences in the size and shape of plasmodia and spores indicate that $M$. paksensis should be regarded as a new species.

\section{Discussion}

Since Andree et al. (1999) first compared the $18 \mathrm{~S}$ rDNA sequences of some Myxobolus spp., researchers have been provided with an excellent tool for differentiating new, host-specific species from known species infecting closely related fishes, which have in most cases morphologically similar spores (Eszterbauer, 2002). Using this method and comparing the sequence differences, there is no need anymore to perform tiresome and long-lasting cross-infection experiments for identifying new species. Studies on salmonid and cyprinid fishes showed the existence of relatively loose or strict host-specificity in species of Myxobolus. Some species, such as M. cerebralis Hofer, 1903, are able to infect salmonids belonging to different genera, e.g. Salmo (L.), Salvelinus Richardson and Oncorhynchus Suckley (see El-Matbouli et al., 1999; Hedrick et al., 2001; Ferguson et al., 2008). In a similar way, M. pseudodispar Gorbunova, 1936 might occur in cyprinid fishes from different subfamilies (Molnár et al., 2002). Other Myxobolus spp. show a relatively strict host range and infect only a single host or some closely related fish species (Marton \& Eszterbauer, 2011; Cech et al., 2012). In a study on the host-specificity of some Myxobolus spp. in closely related cyprinids of the subfamilies Leuciscinae and Abraminae, Cech et al. (2012) found that morphologically similar spores of Myxobolus spp. infecting hosts of the leuciscine genera Rutilus
430

431

432

433

434

435

436

437

438

439

440

441

442

443

444

445

446

447

448

449

450

451

452

453

454

455

456

457

\begin{tabular}{|l|lll|}
\hline & Journal : Medium 11230 & Dispatch : 27-6-2015 & Pages : 12 \\
Article No. : 9589 & $\square$ LE & $\square$ TYPESET \\
& MS Code : SYPA-D-15-00042 & $\checkmark \mathrm{CP}$ & $\checkmark$ DISK \\
\hline
\end{tabular}


Rafinesque, Leuciscus and Aspius (Agassiz) were identical with those of $M$. intimus, but similar spores from the abramine Blicca bjoerkna (L.) exhibited different sequences and proved to be a new species, $M$. eirasianus. Chondrostoma nasus is classified within the subfamily Leuciscinae (see Briolay et al., 1998; Zardoya \& Doadrio, 1999) but differs from other members of this subfamily by its mouth structure and feeding habits. In spore morphology, in the location of plasmodia and in the close relationship of the $18 \mathrm{~S}$ rDNA sequences the species found in $C$. nasus in the present study show very close relationships with some species infecting well-studied fish species of the subfamily Leuciscinae (Figs. 1, 2), e.g. the ide Leuciscus idus (L.), the chub Squalius cephalus (L.) and the roach Rutilus rutilus (L.) (Molnár et al., 2010; Cech et al., 2012), but the remarkable differences found in the sequences prove that they are closely related but distinct new species.

The two phylogenetic algorithms (ML and $\mathrm{BI}$ ) yielded very similar topologies; differences are usually at the nodes with low support (bootstrap and posrterior probabilities under 70). The three new species clustered together with morphologically similar species which also exhibit the same tissue specificity. The only major difference is the position of $M$. sitjae, which was associated with M. szentendrensis $\mathrm{n}$. sp. by BI analysis, but into the same group (containing M. intimus, M. alvarezae Cech, Molnár \& Székely, 2012, M. dujardini Thelohan, 1892, M. obesus and M. eirasianus), but with a more basal location by ML analysis.

The data obtained in this study resulted in the description of three new species of Myxobolus. Although the differences found in the 18S rDNA sequences clearly support the host-specificity of the new species described here, the fact that in genetically closely related fishes morphologically similar spores develop in the same locations, indicates their common phylogenetic origin.

Acknowledgements The authors thank G. Pataki for the preparation of drawings and histological slides.

Funding This study was funded by the KTIA-AIK-12-12103-0017 (BIOCLIMATE) programme and by the Hungarian Scientific Research Fund (OTKA, project No. 100132) and by TÁMOP-4.2.2.B-15/1/KONV-2015-0004.
Conflict of interest The authors declare that they have no conflict of interest.

Ethical approval All applicable institutional, national and international guidelines for the care and use of animals were followed. Permit for scientific fishing in Hungary (EHVF/121-1/ 2014) is issued by the Ministry of Agriculture, Hungary.

\section{References}

Andree, K. B., Székely, Cs, Molnár, K., Gresoviac, S. J., \& Hedrick, R. P. (1999). Relationships among members of the genus Myxobolus (Myxozoa: Bivalvidae) based on small subunit ribosomal RNA sequences. Journal of Parasitology, 85, 68-74.

Barta, J. R., Martin, D. S., Libetator, P. A., Dashkevicz, M., Anderson, J. W., Feighner, S. D., Elbrecht, A., PerkinsBarrow, A., Jenkins, M. C., Danforth, H. D., Ruff, M. D., \& Profous-Juchelka, H. (1997). Phylogenetic relationships among eight Eimeria species infecting domestic fowl inferred using complete small subunit ribosomal DNA sequences. Journal of Parasitology, 83, 262-271.

Briolay, J., Galtier, N., Brito, R. M., \& Bouvet, Y. (1998). Molecular phylogeny of Cyprinidae inferred from cytochrome b DNA sequences. Molecular Phylogenetics and Evolution, 9, 100-108.

Cech, G., Molnár, K., \& Székely, CS. (2012). Molecular genetic studies on morphologically indistinguishable Myxobolus spp. infecting cyprinid fishes, with the description of three new species, $M$. alvarezae sp. nov., $M$. sitjae sp. nov. and M. eirasianus sp. nov. Acta Parasitologica, 57, 354-366.

Donec, Z. S., \& Shulman, S. S. (1984). Knidosporidii (Cnidosporidia). In: O. N. Bauer (Ed.), Key to the determination of parasites of freshwater fishes of the USSR, Volume 1. Leningrad: Nauka, pp. 88-251 (in Russian).

Eiras, J. C., Molnár, K., \& Lu, Y. S. (2005). Synopsis of the genus Myxobolus Bütschli, 1882 (Myxozoa: Myxosporea: Myxobolidae). Systematic Parasitology, 61, 1-46.

El-Matbouli, M., Hoffmann, R. W., Schoel, H., McDowell, T. S., \& Hedrick, R. P. (1999). Whirling disease: host specificity and interaction between the actinosporean stage of Myxobolus cerebralis and rainbow trout Oncorhynchus mykiss. Diseases of Aquatic Organisms, 35, 1-12.

Eszterbauer, E. (2002). Molecular biology can differentiate morphologically indistinguishable myxosporean species: Myxobolus elegans and M. hungaricus. Acta Veterinaria Hungarica, 50, 59-62.

Eszterbauer, E. (2004). Genetic relationship among gill-infecting Myxobolus species (Myxosporea) of cyprinids: molecular evidence of importance of tissue-specificity. Diseases of Aquatic Organisms, 58, 35-40.

Eszterbauer, E., \& Székely, Cs. (2004). Molecular phylogeny of the kidney parasitic Sphaerospora renicola from common carp (Cyprinus carpio) and Sphaerospora sp. from goldfish
513

514

515

516

517

518

519

520

521

522

523

524

525

526

527

528

529

530

531

532

533

534

535

536

537

538

539

540

541

542

543

544

545

546

547

548

549

550

551

552

553

554

555

556

$\begin{array}{lll}\text { Journal : Medium 11230 } & \text { Dispatch : 27-6-2015 } & \text { Pages : } \mathbf{1 2} \\ \text { Article No. : } \mathbf{9 5 8 9} & \square \text { LE } & \square \text { TYPESET } \\ & & \end{array}$


(Carassius auratus auratus). Acta Veterinaria Hungarica, 52, 469-478.

Ferguson, J. A., Atkinson, S. D., Whipps, C. M., \& Kent, M. L. (2008). Molecular and morphological analysis of Myxobolus spp. of salmonid fishes with the description of a new Myxobolus species. Journal of Parasitology, 94, 1322-1334.

Hallett, S. L., \& Diamant, A. (2001). Ultrastructure and smallsubunit ribosomal DNA sequence of Henneguya lesteri $\mathrm{n}$. sp. (Myxosporea), a parasite of sand whiting Sillago analis (Sillaginidae) from the coast of Queensland. Australia. Diseases of Aquatic Organisms, 46, 197-212.

Hedrick, R. P., McDowell, T. S., Mukkatira, K., Georgiadis, M. P., \& MacConnell, E. (2001). Susceptibility of three species of anadromous salmonids to experimentally induced infections with Myxobolus cerebralis, the causative agent of whirling disease. Journal of Aquatic Animal Health, 13, 43-50.

Lom, J., \& Arthur, J. R. (1989). A guildeline for preparation of species description in Myxosporea. Journal of Fish Diseases, 2, 151-156.

Lom, J., \& Dyková, I. (1992). Protozoan parasites of fishes. In: Developments in aquaculture and fisheries science, Volume 26. Amsterdam: Elsevier, 315 pp.

Marton, S., \& Eszterbauer, E. (2011). The development of Myxobolus pavlovskii (Myxozoa: Myxobolidae) includes an echinactinomyxon-type actinospore. Folia Parasitologica, 58, 157-163.

Milne, I., Wright, F., Rowe, G., Marshal, D. F., Husmeier, D., \& McGuire, G. (2004). TOPALi: Software for automatic identification of recombinant sequences within DNA multiple alignments. Bioinformatics, 20, 1806-1807.

Molnár, K. (1994). Comments on the host, organ and tissue specificity of fish myxosporeans and on the types of their intrapiscine development. Parasitologia Hungarica, 27, 5-20.

Molnár, K., Eszterbauer, E., Marton, S., Székely, Cs, \& Eiras, J. C. (2012). Comparison of the Myxobolus fauna of common barbel from Hungary and Iberian barbel from Portugal. Diseases of Aquatic Organisms, 100, 231-248.

Molnár, K., Eszterbauer, E., Székely, Cs, Dán, Á., \& Harrach, B. (2002). Morphological and molecular biological studies on intramuscular Myxobolus spp. of cyprinid fish. Journal of Fish Diseases, 25, 643-652.

Molnár, K., Marton, S., Eszterbauer, E., \& Székely, C. (2006). Comparative morphological and molecular studies on Myxobolus spp. infecting chub from the River Danube, Hungary, and description of M. muellericus sp. n. Diseases of Aquatic Organisms, 73, 49-61.

Molnár, K., Marton, Sz, Székely, Cs, \& Eszterbauer, E. (2010). Differentiation of Myxobolus spp. (Myxozoa: Myxobolidae) infecting roach (Rutilus rutilus) in Hungary. Parasitology Research, 107, 1137-1150.

Tamura, K., Stecher, G., Peterson, D., Filipski, A., \& Kumar, S. (2013). MEGA6: Molecular Evolutionary Genetics Analysis version 6.0. Molecular Biology and Evolution, 30, 2725-2729.

Thompson, J. D., Higgins, D. G., \& Gibson, T. J. (1994). CLUSTAL W: improving the sensitivity of progressive multiple sequence alignment through sequence weighting, position-specific gap penalties and weight matrix choice. Nucleic Acids Research, 22, 4673-4680.

Zardoya, R., \& Doadrio, I. (1999). Molecular evidence on the evolutionary and biogeographical patterns of European cyprinids. Journal of Molecular Evolution, 9, 227-237.

\begin{tabular}{|l|lll|}
\hline & Journal : Medium 11230 & Dispatch : 27-6-2015 & Pages : 12 \\
Article No. : 9589 & $\square$ LE & $\square$ TYPESET \\
MS Code : SYPA-D-15-00042 & $V_{\mathrm{CP}}$ & $\checkmark$ DISK \\
\hline
\end{tabular}


Journal : 11230

Article : 9589

黛 Springer

the language of science

\section{Author Query Form}

\section{Please ensure you fill out your response to the queries raised below and return this form along with your corrections}

Dear Author

During the process of typesetting your article, the following queries have arisen. Please check your typeset proof carefully against the queries listed below and mark the necessary changes either directly on the proof/online grid or in the 'Author's response' area provided below

\begin{tabular}{|l|l|l|}
\hline Query & Details Required & Author's Response \\
\hline AQ1 & Please check and confirm the affiliation details. & \\
\hline
\end{tabular}

